\title{
METODE ANALISIS BIAYA POTONG PADA RUMAH POTONG HEWAN DI KABUPATEN BANDUNG
}

\author{
R. Tawaf ${ }^{1 \mathbf{a}}$, L. Herlina ${ }^{1}$ dan A. Fitriyani ${ }^{1}$ \\ ${ }^{I}$ Departemen Sosial Ekonomi Pembangunan Peternakan, Fakultas Peternakan Universitas Padjadjaran \\ aemail: rochadi@unpad.ac.id
}

\begin{abstract}
Abstrak
Biaya pemotongan ternak sapi disetiap RPH ternyata berbeda-beda besaran nilai dan cara penetapannya. Pada umumnya, dasar yang digunakan adalah perbandingan terhadap harga yang berlaku di suatu wilayah. Sampai saat ini, belum diperoleh informasi yang lengkap mengenai cara analisis biaya potong yang dapat dipertanggung jawabkan. Berdasarkan hal tersebut, penelitian ini bertujuan untuk mendapatkan metode analisis biaya potong di RPH kabupaten Bandung. Metode analisis biaya pemotongan hewan di RPH yang standar diperlukan guna dapat dipertanggungjawabkan dan menimbulkan iklim kondusif bagi para pihak, terutama bagi pelaku usaha dan kegiatan pelayanan RPH itu sendiri. Penelitian ini merupakan sensus di RPH pemerintah kabupaten Bandung. Konsep "kontribusi minimal dari Nilai Tambah ternak" yang diterjemahkan sebagai "biaya potong sebesar 1\% dari kenaikan nilai tambah ternak" kedalam rumus matematika. Kesimpulan penelitian ini adalah : Konsep "biaya potong sebesar $1 \%$ dari kenaikan nilai tambah ternak" dengan metode "kontribusi minimal dari Nilai Tambah ternak", dapat digunakan sebagai pedoman bagi penetapan retribusi RPH sapi potong. Metode ini dapat dikembangkan dan digunakan bagi ternak kerbau, kuda, kambing, domba juga Unggas dengan didahului oleh penelitian yang lebih spesifik bagi masing-masing komoditi ternak tersebut.
\end{abstract}

Kata Kunci : Biaya Potong, Rumah Potong Hewan, Kontribusi dan nilai tambah

\section{Slaughtering Cost Analysis Method on Abattoirs in Bandung Regency}

\begin{abstract}
The cost of slaughtering cattle in each abattoir turns out to vary in value and method. In general, the basis used is a comparison of the prices prevailing in an area. Until now, there is no complete information about the method of analyzing slaughtering costs that can be accounted for. Based on this, this study aims to obtain a method of analyzing slaughtering costs in the Bandung District abattoir. The method of analyzing the cost of slaughtering animals in standardized is needed in order to be accountable and create a conducive climate for business actors and slaughterhouse service activities themselves. This study were census on the government abattoir Bandung regency. The concept of "minimal contribution from Value Added of the cattle" which translates as "slaughtering costs by $1 \%$ of the increase in value added of the cattle" into the language of mathematical equation. The conclusions of this study are: The concept of "slaughtering costs by $1 \%$ of the increase in value added of the cattle" with the method of "minimal contribution of Value Added of the cattle", can be used as a guide for the determination of beef cattle slaughterhouse fees. This method can be developed and used for buffaloes, horses, goats, sheep and poultry, also preceded by more specific research for each of the livestock commodities.

Keywords: slaughtering Cost, abattoir, Contribution and added value
\end{abstract}

\section{Pendahuluan}

Kebutuhan daging segar untuk konsumsi rumah tangga maupun untuk industri pengolahan daging sapi di wilayah pusat konsumen dihasilkan oleh rumah potong hewan (RPH). RPH merupakan unit pelayanan masyarakat 
dalam penyediaan daging yang aman, sehat utuh, halal (ASUH) serta sebagai sarana untuk melakasanakan tempat penyembelihan hewan secara benar, tempat melaksanakan pemeriksaan hewan sebelum dan setelah dipotong serta tempat pemantauan dan surveilans penyakit hewan dan zoonis (Subadyo, 2017). RPH sebagai lembaga penyedia daging sapi segar di Jawa Barat, khususnya di Kabupaten Bandung hingga saat ini sebagian besar kondisinya masih belum sesuai dengan standar SNI (Tawaf, 2013). Walaupun, berbagai kebijakan mengenai standarisasi RPH telah dimiliki pemerintah, antara lain SNI tentang RPH dan NKV untuk menghasilkan daging yang aman, sehat, utuh dan halal (ASUH). Dampaknya dari kondisi tersebut terhadap produk yang dihasilkannya sangat merugikan konsumen maupun produsen. Hal ini ditunjukan oleh rendahnya kualitas dan tingginya harga daging sapi yang dihasilkan $\mathrm{RPH}$.

Berdasarkan hasil penelitian Tawaf (2016) bahwa kondisi pelayan RPH di kabupaten Bandung masih berada pada kondisi yang belum sesuai dengan standar SNI. Beberapa hal yang perlu perhatian adalah :

a. Kondisi fisik sebagian RPH yang beroperasi pada saat ini masih belum mencapai kriteria minimal yang disyaratkan di dalam standar nasional (SNI 01-6159-1999)

b. Prosedur standar operasional pemotongan hewan tampaknya belum dapat diterapkan secara penuh sebagian besar RPH di Kabupaten Bandung.

c. Di dalam proses produksi daging, aktivitas-aktivitas seperti pemotongan daging, pemisahan tulangan (deboning) atau pun pendistribusian produk, masih sering dilakukan secara tidak higienis. Hal ini juga merupakan dampak dari kurangnya fasilitas penanganan produk utama dan produk sampingan.

d. Berdasarkan standar nasional, terdapat beberapa komponen infrastruktur RPH yang juga belum dapat memenuhi standar, terutama yang berkaitan dengan aspek kelengkapannya. Pada aspek ini, terdapat banyak RPH yang belum memisahkan daerah kotor dan daerah bersih. Selain itu, ketersediaan penyediaan air dan instalasi pengolahan air limbah (IPAL) yang layak.

Untuk meningkatkan peran dan fungsi $\mathrm{RPH}$ di dalam menyelenggarakan pelayanan kepada masyarakat tentunya diperlukan upayaupaya pengelolaan yang diarahkan pada peningkatan akumulasi penerimaan dari penyelenggaraan pelayanan tersebut.

Pada persepektif ekonomi, salah satu metode untuk meningkatkan akumulasi penerimaan usaha adalah dengan memperbesar rasio antara manfaat dan biaya pada penyelenggaraan pelayanan tersebut. Rasio yang besar dapat diperoleh dengan memaksimalkan harga / tarif yang dikenakan pada pelayanan, ataupun meminimumkan biaya-biaya yang terdapat pada penyelenggaraan pelayanan tersebut.

Sebagai salah satu lembaga milik pemerintah, RPH tentunya memiliki keterbatasan di dalam menentukan akumulasi penerimaan dari pelayanan yang diselenggarakan. Fakta menunjukkan bahwa beban penyelenggaraan pelayanan pada masyarakat yang dilaksanakan oleh RPH di Kabupaten Bandung cenderung meningkat, sementara besaran tarif yang dikenakan pada setiap jenis pelayanan tidak dapat secara fleksibel berubah mengikuti perkembangan harga. Hal ini tentunya disebabkan karena RPH memiliki keterbatasan berdasarkan tugas dan fungsi pokok yang tercantum di dalam peraturan daerah.

Biaya pemotongan ternak sapi disetiap RPH ternyata berbeda-beda cara penetapannya. Pada umumnya, dasar yang digunakan adalah perbandingan terhadap harga yang berlaku di suatu wilayah. Pada kasus ini, tidak ditemukan biaya produksi yang didasarkan terhadap hasil analisis yang dapat dipertanggung jawabkan.

Berdasarkan hal tersebut, penelitian ini bertujuan untuk mendapatkan metode analisis biaya potong di RPH kabupaten Bandung. Metode analisis biaya pemotongan hewan di RPH yang standar diperlukan guna dapat dipertanggungjawabkan dan menimbulkan iklim kondusif bagi para pihak, terutama bagi pelaku usaha dan kegiatan pelayanan RPH itu sendiri. 
Penelitian ini merupakan sensus di RPH pemerintah di Kabupaten Bandung pada tanggal 10 Juni - 10 Juli 2017. Pendekatan analisis biaya potong hewan di RPH adalah menggunakan konsep "biaya potong sebesar $1 \%$ dari kenaikan nilai tambah ternak" atau dengan kata lain : $1 \%$ dari total nilai tambah ternak yang merupakan biaya normative yang dikeluarkan sebagai biaya pemotongan ternak

\section{Metode Penelitian}

Penelitian ini merupakan sensus, yaitu teknik penentuan sampel jika semua responden digunakan sebagai sampel (Sugiyono, 2008). Sensus dilakukan di RPH pemerintah Kabupaten Bandung pada tanggal 10 Juni - 10 Juli 2016. Penelitian ini menggunakan pendekatan :

a. kepustakaan, terhadap hasil-hasil penelitian atau kajian yang telah dilakukan.

b. Pendekatan partisipatif, merupakan sensus pada pada RPH Milik Pemerintah Kabupaten Bandung yang digunakan untuk melakukan analisis biaya potong para pemangku kepentingan terutama yang berkaitan langsung dengan biaya potong pada RPH. Selain itu juga dilakukan pendekatan dengan Melakukan konsultasi pakar dan konsultasi publik dengan mengadakan serangkaian diskusi untuk memperoleh masukan dan tanggapan dari berbagai pemangku kepentingan.

c. Pendekatan komparatif, digunakan studi perbandingan biaya potong di RPH kabupaten lainnya.

\section{Metode Analisis Data}

Data primer yang berasal dari RPH milik pemerintah dalam bentuk variable yang diamati dikumpulkan, selanjutnya diolah dengan analisis kuantitatif dan disajikan dalam bentuk deskriptif. Konsep pendekatan analisis biaya potong hewan di RPH adalah menggunakan konsep "biaya potong sebesar $1 \%$ dari kenaikan nilai tambah ternak" atau dengan kata lain : $1 \%$ dari total nilai tambah ternak yang merupakan biaya normative yang dikeluarkan sebagai biaya pemotongan ternak. Pengukuran dilakukan terhadap 6 (enam) ekor sapi siap potong Brahman Cross.

\section{Varibel yang diamati :}

- ANT adalah Angka Normatif Tarif (ANT) dengan satuan absolut; yang artinya setiap beban kontribusi sebesar $1 \%$ dari nilai tambah berubahnya bentuk sapi menjadi karkas. Variabel ini merupakan rasio ideal $(1 \%)$ atau $\mathrm{ANT}=$ 1 atau $\frac{A N T}{100}$

- Variabel perubahan nilai tambah yang terjadi setelah terjadi pemotongan ternak, yang dirinci sebagai berikut :

- BB adalah bobot badan hidup hewan dengan satuan kilogram $(\mathrm{Kg})$;

- HNK adalah Harga Non Karkas (jeroan, kaki, kepala dan kulit) dengan satuan Rupiah (Rp);

- PK adalah Rata-rata Persentase Karkas yang dihasilkan setelah pemotongan dengan unit satuan persen $(\%)$;

○ HK adalah Harga Karkas yang berlaku rupiah per $\mathrm{kg}(\mathrm{Rp} / \mathrm{Kg})$.

- HSH adalah Harga Sapi Hidup yang berlaku dengan satuan rupiah per $\mathrm{kg}$ berat hidup $(\mathrm{Rp} / \mathrm{Kg})$

\section{HASIL DAN PEMBAHASAN}

\section{Keadaan umum RPH}

Di kabupaten Bandung, terdapat RPH milik pemerintah dan swasta yang tersebar di beberapa kecamatan dan dimanfaatkan oleh masyarakat. Secara rinci kegiatan RPH dapat dilihat pada Tabel 1. 
Tabel.1.Jumlah RPH Menurut Strata Pemotongan (ekor/ hari)

\begin{tabular}{|l|c|c|c|}
\hline $\begin{array}{c}\text { STRATA JUMLAH } \\
\text { PEMOTONGAN } \\
\text { (EKOR PER HARI) }\end{array}$ & PEMERINTAH & SWASTA & TOTAL \\
\hline I. $\quad$ 1-2 EKOR $*$ & 2 & 15 & 17 \\
\hline II. $3-5$ EKOR & 3 & 10 & 2 \\
\hline III. $\quad>5$ EKOR & 1 & 1 & 32 \\
\hline TOTAL & 6 & 26 & 13 \\
\hline
\end{tabular}

* Termasuk RPH yang pemotongannya tidak rutin dan RPH yang tutup (tidak beroperasi)

Pada Tabel 1, tampak total RPH yang ada di Kabupaten Bandung 32 unit dengan status kepemilikan 6 RPH milik pemerintah dan 26 RPH milik Swasta. Sedangkan berdasarkan jumlah pemotongannya, RPH yang ada di Kabupaten Bandung jumlah pemotongan terbanyak mencapai lebih dari 50 ekor per hari pada RPH MBC milik pemerintah yang terletak di Kecamatan Dayeuh Kolot. Sedangkan RPH dengan jumlah pemotongan 1-2 ekor per hari jumlahnya mencapai 17 unit, 2 unit diantaranya milik pemerintah dan 15 unit lainnya milik swasta atau perorangan. Dalam strata satu juga termasuk RPH yang pemotongannya tidak rutin dan RPH yang sudah tutup (tidak beroperasi). Hal ini sejalan dengan penelitian Narundhana, at al., (2015) bahwa secara bersama-sama atau simultan bahwa faktor berat badan sapi, harga sapi impor, harga sapi lokal dan jenis kelamin berpengaruh terhadap jumlah pemotongan sapi di RPH Pemerintahan Kota Bandung.

Berdasarkan hasil penelitian Tawaf, at al., (2015) ternyata kondisi RPH di Kabupaten Bandung seluruhnya berada pada kondisi tidak layak, berdasarkan standar SNI seperti tampak pada Tabel 2.

SOP RPH di Indonesia yang berlaku secara nasional berdasarkan SNI no. 01-61591999 dan Permentan No. 13/permentan/OT.140/2000 terdiri dari persyartan lokasi, persyaratan sarana, persyaratan bangunan, persyaratan peralatan, dan persyaratan karyawan (Lawu, at al., 2014).
Berdasarkan Tabel 2, tampak bahwa seluruh RPH sampel berdasarkan kelayakan fisik bangunannya serta procedure pemotongan yang dilakukan tidak memenuhi syarat yang ditetapkan SNI. Hal ini sama dengan Tempat Pemotongan Hewan (TPH) Bandar Buat Kota Padang yang dalam operasionalnya belum semuanya memenuhi persyaratan syarat teknis Rumah Potong Hewan sesuai dengan Peraturan Menteri Pertanian Nomor 13/Permentan/OT.140/2010 (Khasrad, at al., 2012).

Namun demikian ada satu RPH (RPH C) yang dapat direkomendasi guna memenuhi persyaratan SNI. Jika dilihat dari Kesmavet dan Hygiene RPH C memiliki nilai 7\% jauh lebih tinggi dibandingkan dengan RPH lainnya walaupun masih kurang dengan Standar yaitu 8\%. Menurut Gaznur, at al., dkk (2017) Proses pemotongan yang dilakukan oleh RPH mengahasilkan daging yang baik ditunjukan dengan TPC, Salmonella sp, Coliform, dan E. Coli berada dibawah batas persyaratan SNI 3932:2008, Air bersih dan limbah cair juga memenuhi baku mutu Peraturan Menteri Kesehatan Republik Indonesia No. 492/Menkes/Per/IV/2010 Lampiran II Tentang Persyaratan Kualitas Air Bersih dan Peraturan Menteri Lingkungan Hidup Nomor 5 Tahun 2015 Tentang Baku Mutu Air Limbah. Hal ini akan sangat berkaitan erat dengan biaya atau besaran retribusi yang harus dibayarkan oleh para pelaku usaha. 
Tabel 2. Penilaian Kondisi RPH Contoh Berdasarkan Kelayakan Fisik dan prosedure

\begin{tabular}{|c|c|c|c|c|c|c|c|c|c|}
\hline & & $15 \%$ & $10 \%$ & $49 \%$ & $10 \%$ & $8 \%$ & $8 \%$ & & \\
\hline NO & RPH & 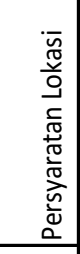 & 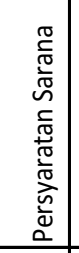 & 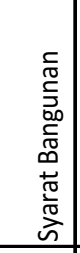 & 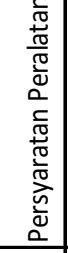 & 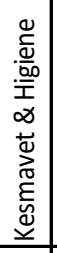 &  & $\begin{array}{l}\overline{\mathbb{\pi}} \\
\stackrel{0}{0} \\
\end{array}$ & 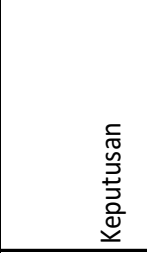 \\
\hline $1 /$ & A & 13.93 & 8 & 31.1 & 1.62 & 1 & 0 & 55.65 & Tidak Layak \\
\hline $2 \mathrm{E}$ & B & 10.71 & 8 & 16.02 & 1.35 & 1 & 2.12 & 39.2 & Tidak Layak \\
\hline $3 \mid c$ & $C$ & 14 & 10 & 36 & 4 & 7 & 2 & 73.00 & Tidak Layak \\
\hline $4[5$ & $D$ & 13.93 & 6 & 20.1 & 1.08 & 1 & 0 & 42.11 & Tidak layak \\
\hline 5 & $E$ & 13.93 & 6 & 17.59 & 1.62 & 1 & 0 & 40.14 & Tidak layak \\
\hline 6 F & $\mathrm{F}$ & 6.43 & 8 & 10.37 & 1.08 & 1 & 0 & 26.88 & Tidak Layak \\
\hline 77 & $\mathrm{G}$ & 15 & 6.67 & 31.52 & 2.16 & 3 & 0.39 & 58.74 & Tidak Layak \\
\hline 815 & $\mathrm{H}$ & 11.54 & 10 & 25.79 & 1.35 & 1 & 0 & 49.68 & Tidak Layak \\
\hline 91 & & 10.71 & 8.33 & 31.93 & 1.89 & 1 & 0 & 53.86 & Tidak Layak \\
\hline
\end{tabular}

Sumber : Tawaf (2015)

\section{Nilai Tambah Ternak}

Berdasarkan hasil penelitian diperoleh data koefisien teknis pemotongan seperti tampak pada Tabel 3 :

BerdasarkanTabel 3, ternyata nilai tambah ternak setelah dilakukan pemotongan dan dijual dalam bentuk karkas dan jeroan terjadi sebesar Rp. 5.807.714,00 atau 25,70\%. Nilai tambah ini, merupakan perubahan bentuk dari seekor ternak sapi menjadi potongan-potongan karkas, jeroan, kaki, kepala, kulit, lemak dan darah. Selanjutnya, akan terjadi perubahan pula, jika karkas diurai atau dirinci lagi dalam bentuk potongan-potongan daging. Berdasarkan hasil penelitian, ternyata para pengusaha penggemukan mengeluarkan biaya proses pemotongan sampai menjadi potongan daging sebesar Rp. 150.000,00/ekor dan biaya pemasaran di Jongko (pengecer di pasar) sebesar Rp. 238.167,00/ekor. Analisis Biaya Potong

Penetapan biaya potong di Kabupaten Bandung, menggunakan konsep "biaya potong sebesar 1\% dari kenaikan nilai tambah ternak" dengan metode "kontribusi minimal dari Nilai Tambah ternak", yang dilakukan dengan menggunakan rumus matematika, dan asumsi-asumsi yang berlaku umum pada saat penelitian. Namun, dalam penelitian ini digunakan data-data lapangan yang dapat terciptanya nilai tambah produk akibat layanan yang diberikan terhadap suatu produk.

Tabel 3. Nilai Tambah dan Koefisien Teknis pemotongan Sapi Brahman Cross

\begin{tabular}{|l|l|l|l|l|l|}
\hline No. & Koefisien teknis & $\%$ & Berat (Kg) & Harga Rp/kg & Total nilai \\
\hline 1 & a. Harga BH & - & 532 & $42.500,00$ & $22.595 .833,00$ \\
& $\begin{array}{l}\text { b. Karkas } \\
\text { c. Jeroan dan Variety } \\
\end{array}$ & 50,00 & 266 & $90.000,00$ & $23.940 .000,00$ \\
& Meat & 171,5 & $26.607,00$ & $4.563 .547,50$ \\
\hline 3 & Nilai Jual (total) & 82,24 & & & \\
\hline
\end{tabular}


Rumus matematika yang digunakan adalah sebagai berikut :

$$
T=\frac{A N T}{100} \times B B\left(\frac{H N K}{B B}+(P K \times H K)-H S H\right)
$$

Dimana:

- $\quad$ T adalah biaya potong atau tarif retribusi RPH dengan satuan rupiah (Rp) per ekor;

- ANT adalah angka normatif tarif dengan satuan absolut, yaitu $1 \%$;

Dengan menggunakan rumus matematika diatas dan asumsi-asumi yang berlaku saat ini, maka tarif retribusi atau biaya potong untuk sapi di RPH Kabupaten Bandung adalah sebagai berikut:

$$
\begin{aligned}
T=\frac{1}{100} \times 532 & \left(\frac{4.561 .360,00}{532}\right. \\
& +(50 \% \times 90.000) \\
& -42.500,00)
\end{aligned}
$$

Berdasarkan hasil analisis, diperoleh tarif retribusi untuk RPH adalah Rp.58.913,60 /ekor, bila dibulatkan menjadi Rp. 60.000,- Bila diperbandingkan dengan biaya potong RPH pada tahun 2011 lalu hingga kini besarnya Biaya Potong dalam bentuk retribusi sebesar $\mathrm{Rp}$. 20.000,00/ekor. Saat itu, harga sapi hidup Rp. $23.000,00 / \mathrm{kg}$; harga karkas Rp. $50.000,00 / \mathrm{kg}$ dan harga edible oval Rp. 1.200,000,00/set. Perbedaan harga yang sangat siginifan ini yang menyebabkan rendahnya biaya potong di tahun 2011 yang lalu.

Biaya pemotongan ini, merupakan pelayanan yang diberikan RPH terhadap proses pemotongan ternak. Pelayanan yang diberikan berupa, pelayanan pemeriksaan kesehatan hewan, listrik, air, tempat pemotongan, sewa kandang istirahat dan surat keterangan kesehatan veteriner.

- ANT adalah angka normatif tarif dengan satuan absolut, yaitu $1 \%$;

- BB adalah bobot badan hidup hewan dengan satuan kilogram $(\mathrm{Kg})$,
- BB adalah bobot badan hidup hewan dengan satuan kilogram $(\mathrm{Kg})$, yaitu rataan BB sapi sampel $532 \mathrm{~kg}$;

- HNK adalah harga pasar Non Karkas dengan satuan (Rp), Rp. 4.561.360,00

- PK adalah Persentase Karkas dengan unit satuan persen (rataan 50\%);

- HK adalah Harga Karkas (Rp/Kg), Rp. $90.000,00$.

- HSH adalah Harga Sapi Hidup (Rp/Kg), Rp. $42.500,00$

Besar kecilnya, biaya ini akan sangat tergantung kepada flukuasi harga sapi hidup dan karkas yang berlaku. Hal ini sesuai dengan penelitian Bagja, at al., (2013) Biaya variabel seperti Jumlah karkas, jumlah ternak, harga beli ternak hidup memberikan pengaruh positif signifikan terhapa pendapatan jagal. Kedua variable tersebut akan sangat menentukan berapa sesungguhnya biaya potong yang harus di bayarkan. Namun demikian, dikarenakan kondisi RPH yang tidak memanuhi standar SNI maka biaya tersebut perlu disesuaikan dengan kondisi pelayanan yang diberikan manajemen RPH tersebut.

\section{Kesimpulan dan Saran}

Konsep "biaya potong sebesar $1 \%$ dari kenaikan nilai tambah ternak" dengan metode "kontribusi minimal dari Nilai Tambah ternak", dapat digunakan sebagai pedoman bagi penetapan retribusi RPH sapi potong, dengan rumus matematika:

$$
T=\frac{A N T}{100} \times B B\left(\frac{H N K}{B B}+(P K \times H K)-H S H\right)
$$

Dimana:

- $\mathrm{T}$ adalah biaya potong atau tarif retribusi RPH dengan satuan rupiah (Rp) per ekor;

- HNK adalah harga pasar Non Karkas dengan satuan (Rp),

- PK adalah Persentase Karkas dengan unit satuan persen (\%);

- HK adalah Harga Karkas (Rp/Kg). 
- $\mathrm{HSH}$ adalah Harga Sapi Hidup (Rp/Kg).

Metode ini dapat dikembangkan dan digunakan bagi ternak kerbau, kuda, kambing, domba juga Unggas dengan didahului oleh penelitian yang lebih spesifik bagi masingmasing komoditi ternak tersebut.

\section{DAFTAR PUSTAKA}

Badan Standarisasi Nasional (1999) SNI Rumah Pemotongan Hewan No. 6159 Tahun. 1999.

Bagja, A., K. Budiraharjo dan D. Sumarjono. (2013) Analisis Pendapatan Jagal Sapi di RPH Penggaron Kota Semarang. Animal Agriculture Journal 2(4).

Gaznur, Zikri Maulina, Henry Nuraini, Rudy P., (2017). Evaluasi Penerapan Standar Sanitasi dan Higien di Rumah Potong Hewan Kategori II. Jurnal Veterniner. Vol 18.

Khasrad, J. Hellyward dan A.D. Yuni (2012). Kondisi Tempat Pemotongan Hewan Bandar Buat Sebagai Penyangga Rumah Pemotongan Hewan (RPH) Kota Padang. Jurnal Peternakan Indonesia. Vol. 14 (2).

Kementrian Pertanian RI (1986) SK Menteri Pertanian no. 555/Kpts/TN.240/9/1986 Tentang Rumah Pemotonga Hewan.

Kementrian Pertanian RI (1992) SK Menteri Pertanian Nomor : 413/Kpts/TN.310/1992
Tentang Prosedur Pemotongan Hewan dan Pemeriksaan Postmortem.

Lawu, Michelia Rambu, Sri Y., Lintang D.S. (2014). Gambaran Pelaksaan Rumah Pemotongan Hewan Babi (Studi Kasus di Rumah Pemotongan Hewan Kota Semarang). Jurnal Kesehatan Masyaraka (e-journal). FKM UNDIP.

Narundha, Disan, R. Tawaf, H. Arief., (2015). Faktor-Faktor yang Mempengaruhi Pemotongan Sapi Impor di Rumah Potong Hewan (RPH) Pemerintahan Kota Bandung.

Subadyo, A. Tutut (2017). Pengelolaan dampak pembangunan Rumah Potong Hewan Ruminansia di Kota Batu. Jurnal ABDIMAS Unmer Malang. Vol 2, Nomor 2.

Sugiyono (2008). Metode Penelitian Kuantitatif Kualitatif dan $R \& D$. Alfabeta. Bandung.

Tawaf, R. Obin Rachmawan dan Andre Daud (2013). Revitalisasi Rumah Pemotongan (RPH) Milik Pemerintah di Jawa Barat. Fakultas Peternakan Universitas Padjadjaran.

Tawaf, R,. Cecep Firmansyah (2016) Kajian Kebutuhan RPH dan RPU di Kabupaten Bandung,. Kerjasama Dinas Peternakan Perikanan Kabupaten Bandung dengan LPPM Unpad. 